\title{
PSYCHOSOCIAL DETERMINANTS OF SATISFACTION WITH HOSPITAL CARE IN ADULT PATIENTS SUFFERING FROM ADVANCED CANCER
}

\author{
Maja Miljanović ${ }^{1}$, Joško Sindik ${ }^{2 \dagger}$, Vibor Milunović ${ }^{3}$, Vesna Kralj Škoc ${ }^{4}$, Marijana Braš ${ }^{5}$, \\ Veljko Đorđević ${ }^{\text {, Jadranka Pavić }}{ }^{7}$ and Lucijano Jakšić ${ }^{1}$
}

${ }^{1}$ Agency for Quality and Accreditation in Health Care and Social Welfare, Department for Quality and Education; ${ }^{2}$ Institute for Anthropological Research; ${ }^{3} \mathrm{Clinical}$ Department of Hematology, Merkur University Hospital; ${ }^{4}$ Clinical Department of Oncology, ${ }^{5}$ Clinical Department of Psychological Medicine, Zagreb University Hospital

Centre; ${ }^{6}$ School of Medicine, University of Zagreb; 'University of Applied Health Sciences, Zagreb, Croatia

SUMMARY - In this observational study, direct and indirect (moderator and mediator) relationships between sociodemographic (age, gender, life partner, education level, income and length of treatment) and psychological (Hospital Anxiety and Depression Scale, HADS) variables and satisfaction with hospital care (EORTC INPATSAT32) in adult (advanced cancer) patients were investigated. Study sample consisted of 75 hospitalized advanced cancer patients recruited at the Zagreb University Hospital Centre and Sestre milosrdnice University Hospital Centre in 2015. Statistically significant negative correlations were found between HADS and elementary school education level, as well as with all satisfaction variables (satisfaction with physicians, nurses and organization). Moderate to high and statistically significant positive correlations were found between elementary school level and all satisfaction variables. Gender and level of education appeared as significant moderator variables in the relationship between HADS and satisfaction with nurse care. There were no significant mediator effects of sociodemographic variables on the correlation between HADS and satisfaction with care. Male participants who were more disturbed emotionally were more satisfied with nurses. Participants with elementary and high school levels of education and lower scores on HADS were more satisfied with nurses, while participants with university level of education had higher HADS scores and lower level of satisfaction with nurses.

Key words: Patient satisfaction; Psychosocial factors; Cancer

\section{Introduction}

Cancer patients usually undergo extensive and debilitating treatments, which make patient satisfaction a very important health care assessment measure. However, many relevant factors contribute to patient satisfaction. This article deals with direct and indirect relationships between chosen sociodemographic and psychological variables, with certain aspects of satis-

Correspondence to: Maja Miljanovic, PhD, Agency for Quality and Accreditation in Health Care and Social Welfare, Planinska 13, HR-10000 Zagreb, Croatia

E-mail: maya.boban@gmail.com

Received June 20, 2016, accepted May 29, 2017 faction with hospital care in adult (advanced cancer) patients.

Cancer is a major public health problem in Croatia. It is the second cause of death after cardiovascular diseases $^{1}$. Around 14,000 people yearly and 1200 people monthly die from cancer. Detailed data about advanced metastatic cancer (e.g., whether patients receive only palliative treatment or a combination of curative and palliative treatment) are missing.

\section{Satisfaction with hospital care}

Health care providers use information on patient satisfaction to make important decisions regarding op- 
erational and treatment plans ${ }^{2}$. Evaluation of the service quality in an oncology setting provides important data concerning patient satisfaction with the quality of care and treatment delivered by physicians, paramedical staff, and the hospital as a whole ${ }^{3}$. A widely accepted conceptual definition of satisfaction with hospital care has not been established ${ }^{4}$. There are, however, different ways of looking at the concept of satisfaction, e.g., the discrepancy theory, the fulfillment theory, the equity theory ${ }^{5}$, the value-expectancy $\operatorname{model}^{6}$, and a tentative model developed by Wilde et $a .^{7}$ and further developed by Larsson and Wilde-Larsson ${ }^{8}$ viewing patient satisfaction as an emotion. The way a person appraises and copes with a situation causally contributes to his/her emotional reaction. In turn, the appraisal process is shaped by interacting person-related conditions and actual, external conditions. Sociodemographic characteristics and the individual's health condition and personality are person-related conditions that affect the person's system of beliefs (expectations) and commitments (preferences).

Therefore, identification of factors that contribute to patient satisfaction can highlight the organizational and operational problems of oncology department and assist in finding solutions to upgrade the quality of services provided. For example, one study suggests that by identifying what is most important to patients, nurses can readily modify the care environment to enhance patient satisfaction with care 9 .

\section{Psychological factors}

It is well known that cancer diagnosis places considerable mental, physical, and emotional stress on patients and requires them to make major adjustments in many key areas of their lives ${ }^{10}$. Cancer patients are at a high risk of a variety of emotional disorders including anxiety, traumatic stress, and depression ${ }^{11-13}$. Consequently, demands on health care providers to satisfy the complex care needs of cancer patients are manifold increased $^{8}$. For example, younger depressed patients who wanted as much information as possible were less likely to be satisfied, even though they received more information than others had ${ }^{14}$. The Hospital Anxiety and Depression Scale (HADS) score was a significant independent predictor of pathological response to chemotherapy, whereas the anxiety score was a significant independent predictor of clinical response ${ }^{15}$.

\section{Sociodemographic and hospital-related features}

Some attention has been paid to the extent to which patient characteristics such as gender, age, educational level, length of hospital stay, self-perceived health status or patient expectations influence their satisfaction with care. The research revealed that there was little consistency in the effect of age on satisfaction with care ${ }^{10}$. Pini et al. ${ }^{16}$ found no statistically significant relationship of overall satisfaction with demographics and other factors, although grading of services seemed to be affected by the patient health status, education and sex. Patient satisfaction was predicted by younger age, female gender, and greater attention to how they were coping with their illness ${ }^{17}$. In comparison to patients with good income level, those with poor income level had a lower level of satisfaction on individualization subscale and proficiency subscale ${ }^{18}$. Brédart et al. ${ }^{19}$ found that patients with a higher than compulsory education level or lower than university level reported lower overall satisfaction. If there is any regularity in the relationship of a specific demographic factor with satisfaction, it will take more research to uncover it, and any relationship will likely be conditioned by other factors ${ }^{10}$.

In this clinical correlation study, the first aim was to determine correlations between psychological (level of emotional distress, coping with the diagnosis) and sociodemographic factors (age, gender, level of education, having life partner or not, and month income), and satisfaction with physicians, nurses and organization of oncology hospital care. The second aim was to determine direct and indirect (mediator and moderator) relationships between the set of psychological and sociodemographic factors (predictors), and satisfaction with physicians, nurses and organization of oncology hospital care (criterion variables).

\section{Patients and Methods}

\section{Participants}

Study sample included hospitalized patients recruited at the Zagreb University Hospital Centre (January 2015) and Sestre milosrdnice University Hospital Centre (April 2015). Initially, the number of included participants was 81 ; however, three patients were excluded due to predefined inclusion (exclusion) criteria (score lower than 26 on the Montreal Cogni- 
tive Assessment (MoCA) test) and three participants declined participation in the study. The inclusion criteria were as follows: 1) advanced stage of disease (grade III/IV) without proven metastasis in the brain or central nervous system (CNS), and without primary malignoma in the brain or CNS; 2) receiving treatment without curative intent; 3) Eastern Co-operative Oncology Group (ECOG) 0 or 1; 4) without acute psychosis, dementia, delirium or psychoorganic syndrome; and 5) score $\geq 26$ on MoCA test. In the final purposeful sample of hospitalized participants, $46(41.3 \%) \mathrm{pa}^{-}$ tients were recruited at the Zagreb University Hospital Centre and 29 (38.7\%) patients at the Sestre milosrdnice University Hospital Centre, i.e. 75 patients in total. According to gender, the sample included 43 (57.3\%) female and $32(42.7 \%)$ male patients, mean age $\mathrm{M}=60.15$ ( $\mathrm{SD}=10.27)$ years. The majority of the participants were married $(\mathrm{f}=55 ; 73.3 \%)$, had high school education $(\mathrm{f}=39 ; 52 \%)$, and below average $(\mathrm{f}=37$; $49.3 \%)$ or average $(\mathrm{f}=29 ; 38.7 \%)$ monthly income. The mean visual analog scale (VAS) for pain was $\mathrm{M}=2.25$ $(\mathrm{SD}=3.5)$ and the mean length of treatment $\mathrm{M}=1.23$ $(\mathrm{SD}=2.45)$ years.

\section{Procedure}

According to the inclusion criteria, participants were recruited by the oncologist and/or head nurse, and then referred to a psychologist. A participant information sheet was provided and written consent obtained from the patients participating in the survey. Data collection started with a short interview and evaluation of cognitive status of the participant. If the participant did not satisfy the minimum score on cognitive assessment, he/she was excluded from the study.

\section{Instruments}

The Montreal Cognitive Assessment (MoCA) test $\mathrm{t}^{20}$ is a popular cognitive screening tool, designed for detection of Mild Cognitive Impairment (MCI) and mild Alzheimer's disease (AD). It is a one-page 30 -point test administered in approximately $10 \mathrm{~min}-$ utes with cut-off score 26 . The test and administration instructions are freely accessible to clinicians at www. mocatest.org. The MoCA assesses several cognitive domains: memory recall (1), visuospatial abilities (2), attention (3), concentration (4), and working memory (5). We used the Croatian version of the test with the approval from Dr Ziad Nasreddine, Neurologist, MoCA@ Copyright Owner. Cronbach's alpha coefficients varied from 0.74 to 0.92 , depending on the population explored ${ }^{21}$.

The European Organization for Research and Treatment of Cancer (EORTC) IN-PATSAT32 questionnaire ${ }^{22}$ was used for the purpose of the survey. This is a 32-item satisfaction with care questionnaire to measure patient appraisal of three scales: hospital doctors (physicians) (1), nurses (2), and the aspects of care organization and services (3). The questionnaire is organized into eleven multi-item scales, including doctors' and nurses' technical skills (e.g., knowledge, experience, assessment of physical symptoms), interpersonal skills (e.g., interest, willingness to listen), information provision (e.g., about the disease, medical tests, and treatment), and availability (e.g., time devoted to patients); other hospital staff members' interpersonal skills; wait times; hospital access; and three single items consisting of information exchange, hospital comfort and overall satisfaction. A "poor", "fair", "good", "very good", or "excellent" response scale is used to rate each aspect of care. The tool has been validated internationally, and has been widely used for the evaluation of oncology services, as well as to highlight aspects of care needing improvement in an oncology setting (Cronbach's alpha coefficients ranged from 0.80 to 0.96$)^{22}$. We used the Croatian version of the questionnaire after completing User's Agreement. To determine the moderator and mediator influences on satisfaction with hospital care, we used factorial approach in summarizing the EORTC IN-PATSAT32 scores to assess these particular aspects of patient satisfaction.

The Hospital Anxiety and Depression Scale $(\mathrm{HADS})^{23}$ is commonly used to determine the levels of anxiety and depression in patients with physical health problems. The HADS consists of 14 items on a four-point response scale ranging from 0 to 3 . The summary scale scores for anxiety ( 7 items) and depression ( 7 items) thus range from 0 to 21 . We used the Croatian version of the assessment with permission of the GL Assessment, Mapi Research Trust. Conducted analysis of the underlying latent structure showed that in the Croatian sample of patients suffering from advanced cancer, most convenient was the one-factorial solution with the unique HADS total score (named "emotional disturbance"), which is used in regression 
equations (Cronbach's alpha coefficient was 0.77 ; optimal cut-off score is 11/12).

\section{Statistical analysis}

The a priori power analysis estimated that a sample size of 54 patients was needed to detect an anticipated large effect size $(\mathrm{f} 2=0.35)$, for all nine predictors, with a power of 0.80 and significance level of $p=0.05$. In analyses with only two predictors to detect an anticipated medium effect size $(f 2=0.15)$, with the same power and significance levels, a sample of 67 participants was needed. Therefore, in the majority of analyses, the sample included in our study $(\mathrm{N}=75)$ was satisfactory for the given research purposes.

Firstly, correlation coefficients (Spearman) among all the variables used in the study were calculated. The second step was to determine the moderating and mediating role of each sociodemographic variable on the relationship between the psychological variables (emotional distress) and satisfaction with physicians, nurses and organization, using hierarchical multiple regression analysis. All interval variables were mean-centered. To put binary variables (i.e. gender, life partner, as well as certain educational levels such as elementary school, high school and college/university) in the linear regression equation, these variables are coded as dummy variables. In our regression analyses, criterion variables were satisfaction with physicians, nurses and organization. Predictor was emotional disturbance (HADS total score). Sociodemographic variables (age, gender, education level, income and duration of medical treatment) were multiplied with emotional disturbance and then set as moderators. Squared semipartial correlation coefficient between the criterion and this product (between sociodemographic variables and emotional disturbance) was used as a measure of moderating effects.

To determine the possible mediator effect of sociodemographic variables on the relationship between emotional distress and satisfaction, in the first step we used all sociodemographic variables as predictors of emotional distress. Confirmation of mediation entails determination of the reduction in size, or determining the significance of the regression coefficient for the predictor (which previously contributed significantly to the explanation of the criteria) with a mediator, which significantly contributed to the explanation of the criteria.
For conducting all statistical analyses, the $\mathrm{R}$ software ${ }^{24}$ was used, with the significance of correlations and regression coefficients set at the level of $\mathrm{p}<0.05$.

\section{Results}

In order to determine the relationship between sociodemographic (age, gender, life partner, education level, income and length of treatment) and psychological (HADS) variables, and satisfaction with hospital care we calculated Spearman correlation coefficients. Table 1 shows low but statistically significant negative correlations between HADS and elementary school education level $(\mathrm{r}=-0.366)$, as well as with all satisfaction variables (satisfaction with physicians $\mathrm{r}=-$ 0.366; satisfaction with nurses $r=-0.333$; and satisfaction with organization $\mathrm{r}=-0.471 ; \mathrm{p}<0.05$ all). On the other hand, moderate to high and statistically significant positive correlations were found between elementary school level and all satisfaction variables (satisfaction with physicians $r=0.599$; satisfaction with nurses $r=0.813$; and satisfaction with organization $r=0.885$; $\mathrm{p}<0.05$ all).

The next step was exploring the possible moderator effect of sociodemographic variables on the association between HADS and satisfaction. Table 2 shows that none of the interactions between emotional disturbance (HADS) and sociodemographic variables (age, gender, education level, income, length of treatment and life partner) was significant in predicting the criterion of satisfaction with doctors $(\mathrm{F}=1.590 ; \mathrm{df} 1=8$; $\mathrm{df}=58 ; \mathrm{p}=0.148)$. Furthermore, none of the interactions between emotional disturbance (HADS) and sociodemographic variables (age, gender, education level, income, length of treatment and life partner) was significant in predicting the criterion of satisfaction with organization of care $(F=2.163 ; \mathrm{df} 1=7 ; \mathrm{df} 2=55$; $\mathrm{p}=0.052$ ).

Statistically significant $F$ change $(F=2.900 ; d f 1=8$; $\mathrm{df} 2=53 ; \mathrm{p}=0.009$ ) was found when forecasting the criterion of satisfaction with nurses using one or more interactions between emotional disturbance (HADS) and sociodemographic (age, gender, education level, income, length of treatment and life partner) as predictors. Thus, we applied backward elimination method, leaving only statistically significant predictors in linear multiple regression equation (Table 3 ). 


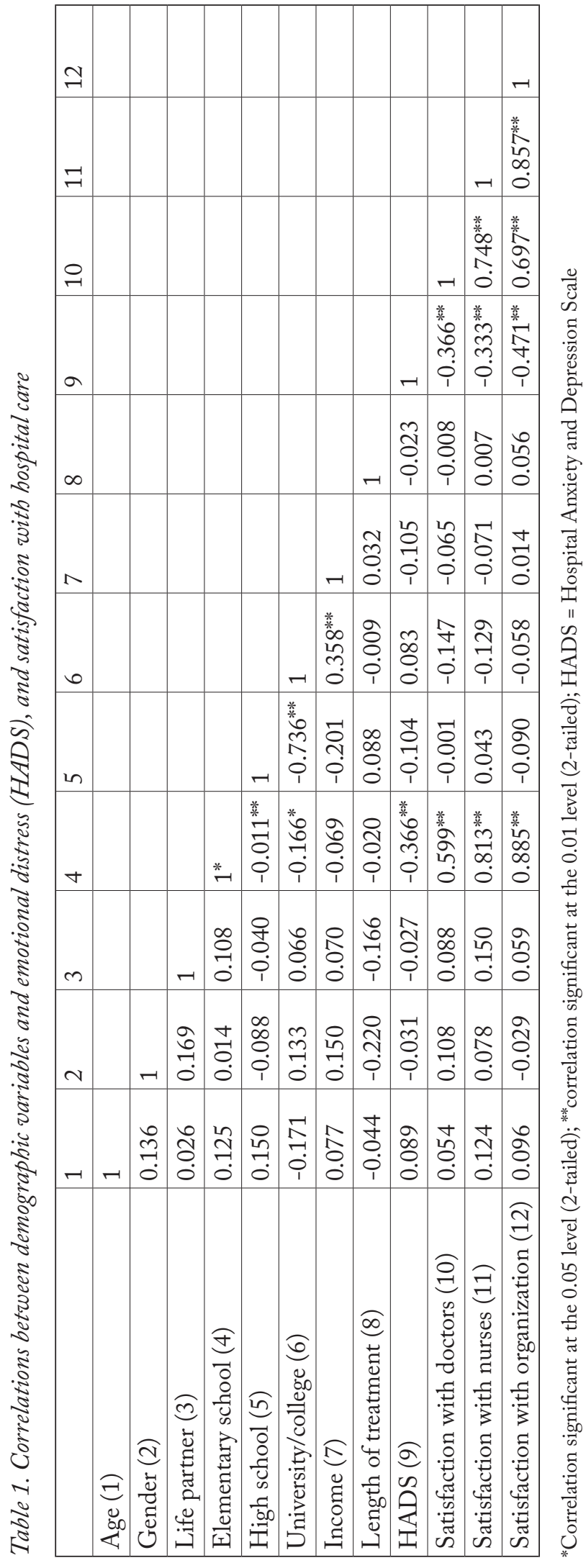

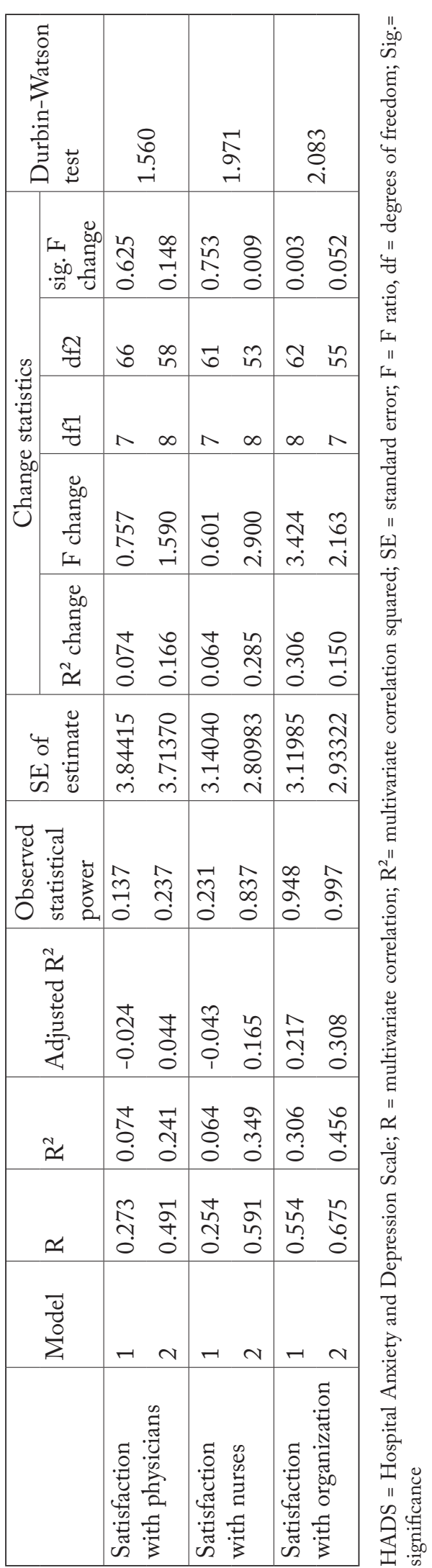


Table 3. Backward elimination of nonsignificant moderators (interactions between emotional disturbance (HADS) and sociodemographic variables) for the criterion satisfaction with nurses

\begin{tabular}{|l|l|l|l|l|l|l|l|}
\hline & \multicolumn{2}{|l|}{$\begin{array}{l}\text { Unstandardized } \\
\text { coefficients }\end{array}$} & $\begin{array}{l}\text { Standardized } \\
\text { coefficients }\end{array}$ & $\mathrm{t}$ & \multirow{2}{*}{ Sig. } & \multicolumn{2}{l|}{$95 \%$ CI for B } \\
\cline { 2 - 8 } & $\mathrm{B}$ & $\mathrm{SE}$ & Beta & & & lower bound & upper bound \\
\hline Gender \& HADS & 0.286 & 0.100 & 1.038 & 2.853 & 0.006 & 0.085 & 0.488 \\
Elementary school and HADS & -0.448 & 0.157 & -0.492 & -2.851 & 0.006 & -0.763 & -0.133 \\
High school and HADS & -0.537 & 0.161 & -0.767 & -3.343 & 0.001 & -0.859 & -0.215 \\
University/college and HADS & -0.596 & 0.170 & -0.969 & -3.507 & 0.001 & -0.937 & -0.256 \\
\hline
\end{tabular}

HADS = Hospital Anxiety and Depression Scale; B= unstandardized regression coefficient; $\mathrm{SE}=$ standard error; Beta= standardized regression coefficient; $\mathrm{t}=\mathrm{t}$ test; Sig. = significance; $95 \% \mathrm{CI}=95 \%$ confidence interval

Table 4. Mediator analysis: emotional disturbance (HADS) and sociodemographic variables (age, gender, education level, income, length of treatment and life partner) as predictors for the criteria satisfaction with physicians, nurses and organization

\begin{tabular}{|c|c|c|c|c|c|c|c|}
\hline Criterion & Model & Predictor & B & SE & Beta & $\mathrm{t}$ & Sig. \\
\hline \multirow{3}{*}{$\begin{array}{l}\text { Satisfaction } \\
\text { with physicians }\end{array}$} & 1 & HADS & -0.189 & 0.057 & -0.366 & -3.336 & 0.001 \\
\hline & 2 & HADS & -0.193 & 0.056 & -0.373 & -3.459 & 0.001 \\
\hline & & Elementary school & 2.213 & 1.142 & 0.209 & 1.938 & 0.057 \\
\hline \multirow{3}{*}{$\begin{array}{l}\text { Satisfaction } \\
\text { with nurses }\end{array}$} & 1 & HADS & -0.137 & 0.047 & -0.333 & -2.887 & 0.005 \\
\hline & 2 & HADS & -0.139 & 0.047 & -0.339 & -2.940 & 0.005 \\
\hline & & Elementary school & 1.081 & 0.999 & 0.125 & 1.082 & 0.283 \\
\hline \multirow{3}{*}{$\begin{array}{l}\text { Satisfaction } \\
\text { with organization }\end{array}$} & 1 & HADS & -0.226 & 0.051 & -0.471 & -4.435 & 0.000 \\
\hline & 2 & HADS & -0.231 & 0.050 & -0.483 & -4.659 & 0.000 \\
\hline & & Elementary school & 2.169 & 1.002 & 0.224 & 2.164 & 0.034 \\
\hline
\end{tabular}

HADS = Hospital Anxiety and Depression Scale; B = unstandardized regression coefficient; $\mathrm{SE}=$ standard error; Beta = standardized regression coefficient; $\mathrm{t}=\mathrm{t}$ test; Sig. = significance;

Gender and level of education appeared as the statistically significant moderator variables in the relationship between HADS and satisfaction with nurses (Table 3). Since the variable 'elementary school' correlated statistically significantly with HADS and satisfaction with doctors, nurses and organization, we performed mediation analysis to determine the possible mediator influence of the elementary school educational level on the relationship between HADS and satisfaction variables. In all three cases, Beta coefficients for HADS did not change their values and their belonging significances after adding suspect mediator variable (elementary school) into the model of predicting satisfaction with doctors, nurses and organization (Table 4). Thus, the variable elementary school education level should have been excluded as a mediator in this study.

\section{Discussion}

The first finding was that direct relationships between sociodemographic variables (age, gender, income, length of medical treatment, high school and university level of education) and HADS, as well as the domains of patient satisfaction, were nonsignificant. Experientially, although some of the sociodemographic variables could be expected to be significantly related to HADS or the domains of patient satisfaction (e.g., short period of medical treatment, low income, etc.), it turned out that these variables were most likely related with satisfaction only in a joint complex combination of features.

We recorded a statistically significant moderator effect of gender and level of education on the satisfaction with nurses. According to our results, male par- 
ticipants who were more emotionally disturbed were more satisfied with nurses (and vice versa, female participants who were less emotionally disturbed were less satisfied with nurses). Theoretically, gender might affect the mean level of patient satisfaction, or the relative strength of predictors of satisfaction. The evidence for gender differences in satisfaction levels about medical care is mixed. Some authors report a preponderance of evidence that women are more satisfied than men with medical care received ${ }^{25}$, whereas others offer findings that women are more critical of medical care than $\mathrm{men}^{26}$. A meta-analysis of 110 studies of patient satisfaction using standard instruments concludes that there is no average difference in satisfaction with medical care between women and men ${ }^{27}$.

Hence, one possible reasonable explanation of our results could be that emotionally disturbed male participants did not want to express their true feelings. In other words, male participants possibly wanted to 'hide' their psychological state, saying that they were satisfied with care and that there was no need for improvement. Research shows that the quality of communication with providers also may be a more important determinant of women's than men's satisfaction with primary care. Research findings show that women are more likely to actively seek information from providers (than men do), as well as to express more emotional content on medical encounters ${ }^{28,29}$.

Second important finding of this study was the fact that the participants with elementary school level of education were less emotionally disturbed and more satisfied with physicians, nurses and organization. Furthermore, our results show that the participants with elementary and high school level of education achieved lower scores on HADS and were more satisfied with nurses, whereas the participants with university level of education achieved higher HADS scores and lower level of satisfaction with nurses. One reasonable explanation for these results could be everyday life experience that less educated people are often less demanding customers, and prefer to accept their 'destiny' more easily than more educated people. A second possible explanation of this result could be that more years of education broaden the general knowledge of a person, so she/he is more aware of the possible (realistic) outcomes of advanced disease. Therefore, she/he probably has more rumination about it. Onwards, it is possible that highly educated participants cannot accept easily that their life and everything is not under their control and engage all of their mental capacities toward 'gaps' in their medicine care. This result is not consistent with studies on the connection between depression, anxiety and education level. Namely, it is well argued that higher education is associated with lower likelihood of depression and anxiety ${ }^{30}$. Individuals with higher education have and use more health resources (such as better ability to avoid chronic stressors and healthier lifestyles), which have beneficial and cumulative effects on health ${ }^{31}$. Some studies found low-level education to be a predicting factor for depression in cancer patients ${ }^{32}$.

Among the limitations of the study, it should be noted that it was an observational (correlation) study without control group. In spite of using Croatian versions of imported measuring instruments, cultural bias could have influenced the results, especially in measuring instruments with psychological components (HADS and IN-PATSAT32). The attending physicians or nursing staff sometimes made referrals. In future studies, a larger and more representative sample of participants should provide better possibility for generalization of the results obtained.

\section{Conclusions}

There is a statistically significant correlation between elementary school level of education, HADS and satisfaction with physicians, nurses and organization. The interaction of HADS and gender, and HADS and levels of education is a significant predictor of satisfaction with nurses. Male participants who are more emotionally disturbed are more satisfied with nurses. Participants with elementary and high school level of education with lower scores on HADS are more satisfied with nurses, whereas those with university education have higher HADS scores and lower level of satisfaction with nurses. However, the main novelty of the study is more complex consideration of the factors that contribute to satisfaction with hospital care in advanced cancer patients. Namely, the role of moderating and mediating effects between chosen predictors was considered, together with insight into direct (correlation) relationships between the study variables.

\section{Acknowledgments}

First author would like to appreciate cooperation and coordination of hospital directors and staff of the 
Zagreb University Hospital Centre, Clinical Department of Oncology, and Sestre milosrdnice University Hospital Centre, Clinical Department for Tumors, including all the study participants.

This research was part of the project entitled Palliative Care in Croatia: Attitudes and Needs of Medical Personnel and Patients Suffering from Advanced Cancer, coordinated by the Center for Palliative Medicine, Medical Ethics and Communication Skills (CEPAMET) and funded by Adris Foundation.

\section{References}

1. Croatian National Cancer Registry. Cancer incidence in Croatia 2013. Bulletin No 38. Zagreb: Croatian National Institute of Public Health; 2015.

2. Crow R, Gage H, Hampson S, Hart J, Kimber A, Storey L, et $a l$. The measurement of satisfaction with healthcare: implications for practice from a systematic review of the literature. Health Technol Assess. 2002;6(32):1-244. doi:http://dx.doi. org/10.3310/hta6320

3. Cleary P. The increasing importance of patient surveys. Now that sound methods exist, patient surveys can facilitate improvement. BMJ. 1999;319(7212):720-1. doi: 10.1136/bmj. 319.7212.720

4. Merkouris A, Ifantopoulos J, Lanara V, Lemonidou C. Patient satisfaction: a key concept for evaluating and improving nursing services. J Nurs Manag. 1999;7(1):19-28. doi: 10.1046/ j.1365-2834.1999.00101.x

5. Messick D, Cook K. Equity theory: psychological and sociological perspectives. New York: Praeger; 1983.

6. Linder-Pelz S. Toward a theory of patient satisfaction. Soc Sci Med. 1982;16(5):577-82. doi:10.1016/0277-9536(82)90311-2

7. Wilde B, Larsson G, Larsson M, Starrin B. Quality of care. Development of a patient-centred questionnaire based on a grounded theory model. Scand J Caring Sci. 1994;8(1):39-48. doi: 10.1111/j.1471-6712.1994.tb00223.x

8. Larsson G,Wilde-Larsson B. Quality of care and patient satisfaction: a new theoretical and methodological approach. Int J Qual Health Care. 2010;23(2):228-47. http://dx.doi.org/ $10.1108 / 09526861011017120$

9. Gourdji I, McVey L, Loiselle C. Patients' satisfaction and importance of ratings of quality in an outpatient oncology center. J Nurs Care Qual. 2003;18(1):43-55. doi: 10.1097/00001786200301000-00007

10. Lis CG, Rodeghier M, Gupta D. Distribution and determinants of patient satisfaction in oncology: a review of the literature. Patient Prefer Adherence. 2009;3:287-304. doi: https:// dx.doi.org/10.2147/PPA.S6351

11. McClement S, Hack T. Audio-taping the oncology treatment consultation: a literature review. Patient Educ Couns. 1999;
36(3):229-38. doi: http://dx.doi.org/10.1016/S0738-3991(98) 00095-0

12. Stefanek M, Derogatis L, Shaw A. Psychological distress among oncology outpatients. Prevalence and severity as measured with the Brief Symptom Inventory. Psychosomatics. 1987;28(10):530. doi: http://dx.doi.org/10.1016/S0033-3182 (87)72467-0

13. von Gruenigen VE, Hutchins JR, Reidy AM, Gibbons HE, Daly BJ, Eldermire EM, et al. Gynecologic oncology patients satisfaction and symptom severity during palliative chemotherapy.Health Qual Life Outcomes.2006;4:84.doi:10.1186/14777525-4-84

14. Jones R, Pearson J, McGregor S, Gilmour WH, Atkinson JM, Barrett A, et al. Cross sectional survey of patients' satisfaction with information about cancer. BMJ. 1999;319(7219):1247-8.

15. Walker LG, Heys SD, Walker MB, Ogston K, Miller ID, Hutcheon AW, et al. Psychological factors can predict the response to primary chemotherapy in patients with locally advanced breast cancer. Eur J Cancer. 1999;35(13):1783-8. doi: http://dx.doi.org/10.1016/S0959-8049(99)00169-0

16. Pini A, Sarafis P, Malliarou M, Tsounis A, Igoumenidis M, Bamidis $\mathrm{P}$, et al. Assessment of patient satisfaction of the quality of health care provided by outpatient services of an oncology hospital. Glob J Health Sci. 2014;6(5):196-203. doi: 10.5539/gjhs.v6n5p196.

17. Walker MS, Ristvedt SL, Haughey BH. Patient care in multidisciplinary cancer clinics: does attention to psychosocial needs predict patient satisfaction? Psychooncology. 2013;12(3):291300. doi: $10.1002 /$ pon.651

18. Can G, Akin S, Aydiner A, Ozdilli K, Durna Z. Evaluation of the effect of care given by nursing students on oncology patients' satisfaction. Eur J Oncol Nurs. 2008;12(4):387-92. doi: 10.1016/j.ejon.2008.02.004

19. Brédart A, Razavi D, Robertson C, Didier F, Scaffidi E, Fonzo $\mathrm{D}$, et al. Assessment of quality of care in an oncology institute using information on patients' satisfaction. Oncology. 2001; 61(2):120-8. doi:10.1159/000055362

20. Nasreddine Z, Phillips N, Bédirian V, Charbonneau S, Whitehead V, Collin I, et al. The Montreal Cognitive Assessment, MoCA: a brief screening tool for mild cognitive impairment. J Am Geriatr Soc. 2005;53(4):695-9. doi: 10.1111/j.1532-5415. 2005.53221.x

21. Julayanont P, Brousseau M, Chertkow H, Phillips N, Nasreddine Z. Montreal Cognitive Assessment Memory Index Score (MoCA-MIS) as a predictor of conversion from mild cognitive impairment to Alzheimer's disease. J Am Geriatr Soc. 2014; 62(4):679-84. doi: 10.1111/jgs.12742

22. Brédart A, Bottomley A, Blazeby JM, Conroy T, Coens C, D'Haese S, et al. An international prospective study of the EORTC cancer in-patient satisfaction with care measure (EORTC IN-PATSAT32). Eur J Cancer. 2005;41(14):212031. doi: 10.1016/j.ejca.2005.04.041 
23. Zigmond AS, Snaith RP. The hospital anxiety and depression scale. Acta Psychiatr Scand. 1973;67(6):361-70. doi: 10.1111/ j.1600-0447.1983.tb09716.x

24. R Core Team. R: A Language and Environment for Statistical Computing. R Foundation for Statistical Computing; Vienna, Austria. Ver.3.2.3; URL: https://www.R-project.org

25. Weiss GL. Patient satisfaction with primary medical care. Evaluation of sociodemographic and predispositional factors. Med Care. 1988;26(4):383-92. doi: 10.1097/00005650-19880 4000-00007

26. Kaplan SH. Satisfaction surveys: does the information make a difference? Clin Perform Qual Health Care. 1996;4(4):216-7.

27. Hall JA, Dornan MC. Patient sociodemographic characteristics as predictors of satisfaction with medical care: a meta-analysis. Soc Sci Med. 1982;30(7):811-8. doi: 10.1016/02779536(90)90205-7
28. Hall J, Router D. Medical communication and gender: a summary of research.J Gend Specif Med. 1998;1(2):39-42.

29. Roter D, Hall J. Why physician gender matters in shaping the physician-patient relationship. J Womens Health. 1998;7(9): 1093. doi:10.1089/jwh.1998.7.1093

30. Bjelland I, Krokstad S, Mykletun A, Dahl A, Tell G, Tambs K. Does a higher educational level protect against anxiety and depression? The HUNT study. Soc Sci Med. 2008;66(6):1334-45. doi: 10.1016/j.socscimed.2007.12.019

31. Ross C, Wu C. Education, age, and the cumulative advantage in health.J Health Soc Behav. 1996;37(1):104-20. doi: 10.1007/ BF02681006

32. Hong JS, Tian J. Prevalence of anxiety and depression and their risk factors in Chinese cancer patients. Support Care Cancer. 2014;22(2):453-9. doi: 10.1007/s00520-013-1997-y

Sažetak

PSIHOSOCIJALNE ODREDNICE ZADOVOLJSTVA BOLNIČKOM SKRBI U ODRASLIH BOLESNIKA S UZNAPREDOVALIM RAKOM

\author{
M. Miljanović, J. Sindikł, V. Milunović, V. Kralj Škoc, M. Braš, V. Đordević, J. Pavić i L. Jakšić
}

U ovom opservacijskom istraživanju proučavani su izravni i neizravni odnosi između sociodemografskih (dob, spol, životni partner, stupanj obrazovanja, prihodi i duljina liječenja), psiholoških (Hospital Anxiety and Depression Scale, HADS) čimbenika i stupnja zadovoljstva dobivenom bolničkom skrbi (EORTC INPATSAT32) u odraslih bolesnika s uznapredovalim rakom. Uzorak od 75 ispitanika prikupljen je u KBC-u Zagreb i KBC-u "Sestre milosrdnice" tijekom 2015. godine. Pronađene su statistički negativne korelacije između HADS-a i stupnja obrazovanja na razini osnovne škole te između HADS-a i zadovoljstva liječnicima, medicinskim sestrama/tehničarima i organizacijom bolničke skrbi. Pronađena je umjerena do visoka statistički značajna pozitivna korelacija između stupnja obrazovanja na razini osnovne škole i svih oblika zadovoljstva bolničkom skrbi. Spol i stupanj obrazovanja su se pokazali kao značajni moderatori odnosa između HADS-a i zadovoljstva medicinskim sestrama/tehničarima. Nije utvrđen značajan medijatorski utjecaj sociodemografskih varijabla na povezanost između HADS-a i zadovoljstva bolničkom skrbi. Ispitanici muškog spola koji su emocionalno uznemireniji bili su zadovoljniji skrbi dobivenom od medicinskih sestara/tehničara. Ispitanici nižeg stupnja obrazovanja su bili manje emocionalno uznemireni i zadovoljniji skrbi dobivenom od medicinskih sestara, dok su ispitanici višeg stupnja obrazovanja bili emocionalno uznemireniji i manje zadovoljni skrbi dobivenom od medicinskih sestara.

Ključne riječi: Zadovoljstvo bolesnika; Psihosocijalni čimbenici; Rak 